\title{
A drónhasználat jogi szabályozásának nemzetközi trendjei és hazai helyzete ${ }^{1}$
}

\section{ROTTLER Violetta ${ }^{2}$}

\begin{abstract}
A magánbiztonsági ipar átalakulóban van. Néhány szegmensében alapvető és precedens nélküli paradigmaváltáson megy keresztül. A kombinált biztonsági megoldás (élöerő + elektronikus védelem) a trend világszerte, és a drónoknak egyre növekvő szerep jut ebben. E tanulmány célja, hogy rövid áttekintést nyújtson a szabályozás hazai helyzetéről, az Európai Unió drónszabályozási folyamatáról, valamint exemplifikatív módon külföldi jó megoldásokat vonultasson fel. Véleményem szerint a drónok rendészeti alkalmazása a fejlődés egyik iránya, figyelmet kell fordítani a megfelelö normák kialakitására, ebben segíthet a nemzetközi szabályozási trendek megismerése.
\end{abstract}

Kulcsszavak: drón, drónszabályozás

\section{Bevezetés}

Hazánkban a katonai légügyi hatóság kijelöléséről szóló 392/2016. (XII. 5.) Korm. rendelet alapján a Honvédelmi Minisztérium adja ki az engedélyeket a drónok eseti légtérhasználatára. Az engedélykérelmet legalább 30 nappal a drónreptetés előtt be kell nyújtani, ennek tartalmaznia kell a reptetés időpontját, a tervezett útvonal pontos koordinátáit, a repülési magasságot, az átlapoló repterek ${ }^{3}$ üzembentartóinak az engedélyét. Szükséges kellék még a kötelező felelősségbiztosítás megléte is, ezt az engedélykérelemnek szintén tartalmaznia kell. Kell egy biztonsági felmérést is végeztetni, ennek eredményét csatolni az eseti légtérkérelemhez. Az eseti légtérhasználat illetéke 3000 Ft.-ba kerül. 2017. január 1-jétől a sport- és magáncélú drónhasználat bejelentési kötelezettsége megszűnt, viszont az eseti légtérhasználatot engedélyeztetni kell. A drónreptetés kezdőidőpontja előtt 30 perccel telefonon aktiválni kell a légteret és a végén szintén telefonon jelezni kell a határozatban megadott telefonszámon, hogy a drónhasználó a tevékenységet befejezte.

A mű a KÖFOP-2.1.2-VEKOP-15-2016-00001 azonosítószámú, „A jó kormányzást megalapozó közszolgálat-fejlesztés” elnevezésű kiemelt projekt keretében múködtetett Ludovika Kutatócsoport keretében, a Nemzeti Közszolgálati Egyetem felkérésére készült

2 ROTTLER Violetta dr., r. őrnagy, tanársegéd, NKE RTK, Magánbiztonsági és Önkormányzati Rendészeti Tanszék Violetta ROTTLER police major, assistant lecturer, NUPS Faculty of Law Enforcement, Department of Private Security and Local Governmental Law Enforcement

orcid.org/0000-0002-6695-8102, rottler.violetta@uni-nke.hu

3 Átlapoló reptereknek nevezik a légiforgalmi irányítók azon reptereket, amelyek feletti légtér a drón tervezett útvonalát keresztezi. 


\section{A probléma}

A drónhasználat hazai szabályozásának az alábbi nehézségei vannak:

- az engedélyezési folyamat nehézkes;

- az érdekeltek számára nehezen érthető;

- nem felhasználóbarát;

- a sűrün lakott területekre nem fordít kiemelt figyelmet;

- nem vonzó a befektetők számára;

- hiányoznak a garanciális feltételek a biztonságos drónhasználathoz.

A fenti nehézségek kiküszöbölésének érdekében áttekintettem a drónhasználat nemzetközi szabályozási példáit, kiemelve azon elemeket, amelyeknek a magyar joggyakorlatba való átültetése azt átláthatóbbá, az érdekeltek számára könnyen kezelhetővé teszi.

Mielőtt a jogi gyakorlat hazai és nemzetközi elemzésének részleteit ismertetném, néhány gondolat erejéig bemutatom a drón, illetve a légi jármú fogalmát, valamint rövid történeti áttekintést adok. Majd a jogszabályok elemzését követően javaslatot teszek a nemzetközi jó gyakorlatok magyar jogi keretek közé történő átültetésére, valamint bemutatom a fontosabb technológiai vívmányokat, amelyek értelemszerűen magukkal hozzák majd az újabb szabályozási kérdéseket.

\section{Mit nevezünk drónnak?}

„Drónnak a levegőben közlekedő, számítógéppel, vagy híradástechnikai vezérlővel irányított, légijárműnek nem minősülő, azonban kép- és hangrögzítésre alkalmas eszközöket nevezzük."4 Hazánkban az eszköz megnevezésére a legelterjedtebb kifejezés a „drón”, azonban nevezik még „pilóta nélküli légi járműnek” (unmanned air vehicle) is.

\section{Mit nevezünk légi jármúnek?}

$\mathrm{Az}$ 1944-es chicagói egyezmény rendelkezéseiben nem találjuk a légi jármű fogalmi meghatározását, azonban az egyezmény a légi járművek felség- és lajstromjeleiről szóló 7. függeléke pontos definíciót tartalmaz: „légi jármű bármely olyan szerkezet, amelynek levegóben maradását a légkörben a levegővel való kölcsönhatás segíti, amely nem azonos a föld felszínére ható ellenhatással. Ez a kölcsönhatás a levegőnél nehezebb légi járművek esetén az aerodinamikai felhajtóerőtől származik, mert ezek a légi járművek a repülés közben a felhajtóerőt elsősorban az aerodinamikai erőkből nyerik; a levegőnél könnyebb légi jármúvek esetén a fajsúlykülönbségből származik, mert a levegő felhajtóereje tartja ezeket a légi járműveket a levegőben."5 A chicagói egyezmény 3. cikke 
elhatárolja a polgári és állami légi közlekedést, és kimondja, hogy az egyezmény a polgári légi közlekedést szabályozza. (Az állami légi közlekedés szabályozása a belső nemzeti jogra tartozik.) A 8. cikk nevesíti a pilóta nélküli légi járműveket: „olyan légi jármű, amely pilóta nélküli repülésre alkalmas”, és kimondja, hogy a polgári légi közlekedést nem zavarhatja, így a szerződő államok vállalják, hogy ellenőrzik ezen eszközök múködését.

Magyarországon 2016. december 31-én lépett hatályba a légi közlekedésről szóló 1995. évi XCVII. törvény módosítása, ettől kezdve a definíció egyszerűsödött, a 71. $\S$ 35. pontja szerint: „[P]ilóta nélküli légijármú: olyan polgári légijármű, amelyet úgy terveztek és úgy tartanak üzemben, hogy vezetését nem a fedélzeten tartózkodó személy végzi."

\section{A drónok fejlődésének rövid történeti áttekintése címszavakban ${ }^{6}$}

- A kezdetek: hajtómú nélküli fejlesztések (Velence bombázása).

- A légi torpedók kora (Hewitt-Sperry automata repülögép, Larynx).

- A pilóta nélküli célrepülőgépek (Reginald Denny hobby repülője, OQ-3 típusú drón).

- A második világháborús robotok (V-1, JB-2 Doodle Bug robotrepülőgép, BQ-17, TDR-1, FU-GO bomba).

- A hidegháború fejlesztései (AQM-35, Szovjet La-17).

- A vietnami háborúban használt drónok („Tom Cat”, Model 147H UAV).

- Az öbölháború robotjai (Pioneer UAV, BQM-147 Exdrone).

- Szövetséges drónok a Balkán felett (USAF Predator, CL-289).

- Drónok használata a terrorizmus elleni küzdelemben (Global Hawk, Black Hornet, Tarantula Hawk).

\section{A magyar engedélyezés föbb nehézségei}

- Az engedélyezési folyamat nehézkes, mert a rendelkezésre álló humán erőforrás nem megfelelő a kérelmek elbírálásához;

- az érdekeltek számára nehezen érthető, ezért sok esetben kérelem benyújtása nélkül történik a drónhasználat;

- nem felhasználóbarát, mert csak papíralapon történhet a kérelmek benyújtása;

- a sürün lakott területekre nem fordít kiemelt figyelmet, így az állampolgárok biztonsága nem kielégítő;

- nem vonzó a befektetők számára, mert a kiszámíthatóság megkérdőjelezhető;

- hiányoznak a garanciális feltételek a biztonságos drónhasználathoz, így egy káresemény esetén annak megtérítése nehezen realizálható.

\footnotetext{
Dr. Palik Mátyás r. alezredes, egy. doc. előadása alapján, NKE HHK, 2015. október 20.
} 


\section{Nemzetközi kitekintés}

\section{A német drónszabályozás}

Németországban a drón tömegétől függ a szabályozás. 2 kg tömegú, pilóta nélküli légi jármủ a határ, ha nehezebb akkor csak jogosítvánnyal rendelkező drónpilóta reptetheti, aki vizsgázott a használatából. A drón regisztrációja tömegtől függetlenül kötelező. 5 kg feletti drón esetén a légügyi hatóságtól kell engedélyt kérni.

Ebből következően a kis drónok használata nem engedélyköteles, azonban a repülési magasság legfeljebb 100 méter lehet, és külön engedély nélkül nem rögzíthető felvétel a drónnal. Ez a szabályozás az RC vagy modellrepülő-pilótáknak kedvező csak, nem a hobbihasználók többségének, akik szeretnének kép- és videófelvételeket rögzíteni.

Az új német dróntörvény szabályozza, hol repülhetnek a drónok. A felszállási engedély nélküli drónok a modellezési repülootereken kívül csak a látótávolságban, maximum 100 méter magasban repülhetnek. Látótávolságként a szabad szemmel látás értendő, segédeszközök például távcső nélkül. Ezen szabály alól kivétel a minidrónok használata, a 250 grammnál kisebb felszállási súlyú drónok repülhetnek látótávolságon kívül, ilyenkor videoszemüveggel követi a drónpilóta, azonban ezek az eszközök maximum 30 méter magasságban repülhetnek. ${ }^{7}$

A német gyakorlatból javaslom átvenni a videoszemüveg használatát annak érdekében, hogy a 250 gramm alatti tömegü drónok is megfelelöen kontrollálva legyenek a drónhasználat közben, hiszen a relatíve alacsony áruk miatt ezek nagy számban vannakjelen a légtérben.

\section{Nagy-Britannia drónhasználati jogszabályai}

Nagy-Britanniában jelenleg egy 2009-es törvény (Air Navigation Order) két cikke szabályozza a kis méretű, ember nélkül repülő eszközök használatát. Ez a rendelkezés igen szigorú, tiltja a látótávolságon kívüli reptetést, az ütközésekért mindig a drón tulajdonosa a felelős, nem szabad sűrún lakott terület felett röptetni, 50 méternél közelebb szinte semmihez sem mehet a drón, illetve az üzleti célú felhasználáshoz a légi közlekedési hatóság engedélye szükséges. Mindez annyit jelent, hogy egy városban - hacsak nem egy hatalmas parkban végzi a tevékenységet valaki - gyakorlatilag sehol sem lehet drónt reptetni.

A brit gyakorlatból javaslom átvenni azt, hogy egy esetlegesen bekövetkezö baleset során a felelösség a tulajdonost terhelje minden esetben, a kivizsgálás nem a jellemzően túlterhelt rendôri szervek felelössége lesz.

Magyar (2017) 


\section{A japán gyakorlat}

A szigetország 2015. év elején legalizálta a pilóta nélküli, távirányítású légi jármúvek használatát, egyúttal alkalmazásuk feltételeit is meghatározták. Ezt követően szigorították a használatot, főként egy áprilisban történt incidens következtében. 2015. szeptemberében fogadták el a Polgári Repülési Törvény kiegészítését, amely 2015. decemberében lépett hatályba.

A jelenleg hatályos legfontosabb drónhasználati szabályok: ${ }^{8}$

- maximális repülési magasság: 150 méter;

- repülőterektôl való távolság: $9 \mathrm{~km}$;

- (ember)tömeg fölött nem repülhet;

- az áramvezetékektôl megfelelően biztonságos távolságban repülhet;

- a közlekedési joggal összefüggésben a fontosabb közlekedési útvonalak fölött sem repülhet;

- a tulajdonjoggal összefüggésben magánterület fölött sem repülhet a tulajdonos beleegyezése nélkül;

- Oszaka és Tokió városhatárain belül a közparkokban sem lehet használni;

- szigorúan tilos a miniszterelnöki hivatal, a császári palota, a repterek és kritikus infrastruktúrák, például atomerőmúvek fölött repülnie.

Az új törvényi rendelkezés tehát a repterek közelében is megtiltja a drónhasználatot, továbbá a tömegrendezvényekről (fesztiválok, sportesemények) is kitiltja. Az ország azon területein, amelyek nem tartoznak repüléstilalmi övezetbe, maximum 500 láb (150 méter) magasságig repülhetnek és 100 láb (30 méter) távolságra közelítheti meg az embereket, épületeket és járműveket.

Már egy ideje társadalmi nyomás nehezedett a jogalkotásra a drónok szigorúbb szabályozását követelve, de ezt a folyamatot igazán egy 2015. tavaszán történt esemény gyorsította fel, amikor a miniszterelnöki hivatal tetején egy gyanús - feltehetően radioaktív anyagot szállító - drón landolt. Később kiderült, hogy egy aktivista ártalmatlan, merész mutatványáról van csak szó, de a jogalkotási folyamat ennek ellenére beindult. ${ }^{9}$

2015. májusában a naganoi zenei fesztiválon egy 15 éves fiú által irányított drón okozott balesetet, szeptemberben pedig egy 49 éves férfi drónja ütközött az UNESCO világörökség részét képező, Kiotótól mintegy 60 mérföldre nyugatra lévő Himedzsi kastélyba. Egy másik UAV kigyulladt egy bicikliverseny során, szerencsére személyi sérülés nem történt. Ez a drón a szervezők tulajdonát képezte, és a versenyről készített felvételt. Az Egyesült Államokhoz hasonlóan a japán hatóságok is folyamatosan vizsgálják, hogy a kereskedelmi célú drónokat milyen módon lehetne megfelelően szabályozni.

www.uavsystemsinternational.com/drone-laws-by-country/japan-drone-laws/?v=35b5282113b8 (2018. 09. 07.).

Atherton (2015) 
A japán hatóságok 2015. szeptemberében fogadták el a Polgári Repülési Törvény kiegészítését, amely 2015. decemberében lépett hatályba. 2015. december 10-én a szigorúbb szabályzás hatékony érvényesítése végett felállították a Tokiói Metropolitan Rendőrség legújabb drónokat alkalmazó egységét, amelynek a feladata a kisebb jogsértő drónok elfogása. Az egységet a könnyü, erős, stabil „Spreading Wings S900” típusú hexacopterekkel szerelték fel, amelyek mindegyikéhez hálót rögzítettek. Az elfogás leginkább ahhoz hasonlatos, ahogy egy medúza bekebelez egy rákot; a rendőrségi drón egy hálóval van felszerelve, a jogsértő drón, például egy quadcopter fölé repül, ami beleakad a hálóba, ezáltal repülésképtelenné teszi, ahogy a medúza csalánsejtjeivel megbénítja áldozatát. Ezután óvatosan - a sérüléseket elkerülendő - lerakja azt a földre. ${ }^{10}$

$\mathrm{Az}$ antidrón egység fő feladata a repüléstilalmi zóna és a kiemelten fontos objektumok (miniszterelnöki hivatal, parlament épülete, császári palota) védelme a fővárosban. A rendőrök, ha tudják, első lépésként megkeresik a jogsértő drónt irányító személyt, és figyelmeztetik, ha ez nem lehetséges, akkor a rendőrségi drón „behálózza” a jogsértő drónt és lehozza a földre. A rendőrségi drónok 6-10 láb (kb. 1,8-3 méter) hosszúak, kamerával és hálóval felszereltek. A háló 3 méter hosszú és 2 méter széles. A rendőrségi antidrón egység alkalmas lesz a fentebb említett 2015. áprilisi incidenshez hasonló fenyegetések kezelésére is.

Korábban is történt már drónfogás hálóval, azonban az a tény, hogy ezt a Franciaországban kifejlesztett módszert rendőrségi drónok használják, a világon egyedülálló.

Az új szabályzás bírságokat és más szankciókat helyez kilátásba a nem megfelelően használt drónok operátoraira, például az 500 láb (150 méter) maximális repülési magasság figyelmen kívül hagyása esetére. Tokió továbbá kitiltja a 200 grammnál (kb. fél font súlyúnál) nehezebb drónok használatát a sűrűn lakott lakóövezetekből, ebbe egész Tokió területe beletartozik. Ugyanezen méretet jelöli meg az amerikai Szövetségi Légügyi Hatóság (FAA - Federal Aviation Agency) is regisztrációmentesként, habár az FAA ilyen kategorikusan még nem tiltotta ki a városokból a drónokat, ehelyett csak a repterek közelében és speciális zónákban tiltotta meg használatukat.

Japánban a hobbioperátoroknak 10 munkanappal korábban - ami a gyakorlatban 15 naptári napot jelent - be kell jelenteni a minisztériumnak postai úton egy repülési engedély iránti kérelmet, ha repülésmentes zónában akarják használni gépüket. Ezen szabály megszegése minimum 500 ezer JPY (kb. 1230000 HUF) bírsággal jár. Az új szigorú szabályozás csalódást okozott a hobbifelhasználóknak. Egyesek szerint a drónipar fejlődését is visszavetheti. Megoldás lehetne bizonyos helyek kijelölése, ahol bárki szabadon használhatná drónját. ${ }^{11}$

A japán gyakorlatból javaslom átvenni a közüzemektől (például elektromos felszíni vezetékek) való minimális távolság betartását.

$10 \quad \operatorname{Mogg}(2015 b)$

11 Mogg (2015a) 


\section{Új drónszabályozás Dél-Koreában}

A kelet-ázsiai „high-tech” országban az online-vásárlás rohamos terjedése is gyorsította annak a törvénycsomagnak az elfogadását, amely szabályozás lefedi a drónok használatát. A 2017. márciustól kezdve hatályba lépett törvényekkel a korábbi szabályozást, a repülésről szóló törvényt helyezték hatályon kívül, amely addig „ultrakönnyú repülőként" nevesítette a drónokat.

Koreában a maximális reptetési magasság: 150 méter, mindig látótávolságon belül kell hogy maradjon a drón, ami azt jelenti, hogy puszta szemmel láthatónak kell lennie. Kötelező felelősségbiztosítással rendelkezni, ha drónt akarunk regisztráltatni, ennek fedezete minimum 150 millió koreai won (kb. 38 millió forint). A maximális felszállási súly, ha 12 kg-nál több, akkor külön engedély szükséges. A repterektől legalább $9 \mathrm{~km}$ távolságra lehet reptetni. Másik távolságtartási szabály, hogy tömeg fölött sem lehet drónt reptetni. Szöul egésze repüléstilalmi övezet, azonban ahogy azt az előzőekben említettem, van néhány drónröptetésre kijelölt park. A repüléstilalmi zónákat a felhasználók könnyen ellenőrizhetik egy mobiltelefonos applikáció segítségével, amelynek neve: „Ready to Fly”. Napkelte előtt és napnyugta után Koreában tilos drónt reptetni. A speciális szabályok körében elöírás, hogy a kereskedelmi célú drónok irányítóinak kötelező a minisztériumi regisztráció. Koreában a Közlekedési Minisztériumhoz tartozik a drónok nyilvántartása. Kötelező a regisztráció a megrendelésre végzett munka esetén, azonban ha egy cég alkalmazottja végzi a munkát a drónnal, akkor értelemszerúen a cég regisztrál. ${ }^{12}$

A dél-koreai gyakorlatból javaslom átvenni a drónröptetés területi behatárolásának azt a módszerét, amely során egy rendeltetésszerüen müködtetett közparkban jelölnek ki drónparkot. Továbbá az idôbeli behatárolás átvételét is javaslom megfontolni, amely szerint napkelte és napnyugta között lehet használni a drónokat. Szintén a bevezetését javaslom egy nemzeti drónregiszternek, amit egy állami szervezet tart nyilván, illetve müködtet.

\section{Az európai uniós drónszabályozás - egységes biztonsági elöírások Európa-szerte}

Az Európai Parlament plenáris ülésén jóváhagyta a drónokkal kapcsolatos tervezetet. Az EP-képviselők támogatták az Európai Tanáccsal 2017. novemberben leegyeztetett tervezetet. (A képviselők 558 szavazattal, 71 ellenszavazat és 48 tartózkodás mellett fogadták el a javaslatot.)

Az egységes szabályozásnak kettős célja van, egyfelől hogy egységes biztonsági előírásokat fektessen le az unióban a pilóta nélküli légi járművek közlekedésére vonatkozóan, másfelől a gyártók számára megteremteni a termék- és szolgáltatásfejlesztéshez elengedhetetlen jogbiztonságot.

12 Shin \& Kim (2018) 
Az új szabályok értelmében csak olyan drónok építhetők, amelyek müködés közben nem veszélyeztetnek más személyt vagy az adott légteret használó egyéb jármúvet. Kockázati besorolásuk alapján különböző biztonsági funkciókkal kell rendelkezniük. A gép tömegétől vagy üzemelési területétől függően kötelező lesz például az ütközéselhárító rendszer, vagy az automatikus landolási funkció arra az esetre, ha a drón irányítója elveszti a kapcsolatot a géppel. A drónok bizonyos kategóriája felett a drónpilótáknak képzésen kell részt venni és vizsgát kell tenni jártasságukról. Nemzeti drónregisztereket kell létrehozni a drónpilóták és eszközeik regisztrálása végett, hogy baleset esetén azonosítható legyen az üzemeltető. Ez a szabály a kisebb drónokat nem érinti.

A jogszabály szerint az Európai Bizottság feladata lesz, hogy az alapelvek alapján kidolgozza a részletes uniós szabályozást például a drónok maximális sebességére vagy egymástól kötelezően megtartandó távolságra vonatkozóan. Azt is, hogy mely irányítónak és drónnak kell átesnie kockázati tanúsításon, kinek lesz kötelező a képzés, kit kell regisztrálni, és mely drónok esetében lesznek kötelezően előírt további biztonsági funkciók. Az uniós bizottság olyan szabványok kidolgozására is felhatalmazást kap, amelyek segítségével a bajba jutott, nagyobb kategóriájú eszközök fekete dobozából a segítségnyújtás meggyorsítása érdekében letölthetők lesznek a tárolt adatok.

A drónokra vonatkozó uniós szabályzás része az uniós repülésbiztonsági szabályok modernizálásának. A szabályfrissítés célja az volt, hogy az unió repülésbiztonsága továbbra is magas szintû maradjon, ugyanakkor a szabályok praktikusabbak és a kockázati tényezőkkel arányosabbak legyenek a következő évtizedekben várható forgalomnövekedés kezelésére. A szabályok frissítésével továbbá szorosabbra füzik a válságzónák feletti átrepülés engedélyezésével foglalkozó uniós és nemzeti hatóságok közötti együttmúködést is.

A fenti tervezet elfogadása az első mérföldkő az egységes uniós drónszabályozás felé. A részletes szabályozás kidolgozásának folyamata elindult, a későbbiekben kialakított sztenderdeket az egyes tagállamok nemzeti törvényhozásának is implementálni kell majd a saját jogrendszerükbe.

Magyarországon a jogalkotó az uniós szabályozás elkészülésére vár, azonban már történtek lépések a lassú, nehézkes engedélyezés egyszerüsitésére. Megjegyzendő, eddig a jogszerútlen használat miatti szankció kiszabása is csak néhány esetben fordult elő.

Jelenleg a 150 kg-nál könnyebb drónok a nemzeti hatóságok hatáskörébe tartoznak, ezért a gyártóknak és üzemeltetőknek országonként eltérő tervezési és biztonsági előírásoknak kell megfelelniük. A civil dróntechnológia a következő tíz éven belül az uniós repülési piac mintegy 10\%-ára (évi mintegy 15 milliárd euróra) nőhet. Az Európai Bizottság becslése szerint a drónágazat 2050-ig 150 ezer új munkahelyet hozhat létre. $^{13}$

\footnotetext{
13 Jóváhagyták az EU drónszabályozást, folytatódhat az uniós törvényalkotási folyamat. Forrás: https://droninfo.blog. hu/2018/06/12/jovahagytak_az_eu_dronszabalyozast (2018. 09. 07.).
} 


\section{A drónok technológiai vonatkozásai „egy jogász szemüvegén keresztül"}

\section{Repülötértípusok}

Világos, átlátható normák kellenek, de a túl szigorú szabályzás sem célravezető, mert szükség van arra, hogy megteremtsük a biztonságos múködtetés feltételeit a hobbidrónozók számára is. A 2017. július 1-jén hatályba lépett végrehajtási rendelet tartalmazza egy úgynevezett „VII. osztályú repülőtér” kategória bevezetését, amelynek célja, hogy a pilóta nélküli légi jármúvekkel lehessen egy elhatárolt területen légi közlekedési tevékenységet végezni. („VII. osztály: olyan polgári célú, nem nyilvános repülőtér, amelyről kizárólag pilóta nélküli légijárművel végzett légiközlekedési tevékenység végezhető.") E repülőtér üzemeltetéséhez a hosszas hatósági eljárás lefolytatása helyett bejelentési kötelezettséget írnának elő, amely az üzemeltetéshez kapcsolódó alapvető információt tartalmazza. E lehetőség oktatási, kísérleti, kutatás-fejlesztési vagy akár gyakorlási célt szolgálna egy biztonságos, elkülönített területen. A reptértípus megteremtése továbbá lehetőséget teremthet a hagyományos értelemben vett repülőmodellezésre. Hazánkban egyébként összesen 122 repülőtér múködik, többségük irányítás nélküli kis reptér.

Számos külföldi példa is van már arra, hogy miként teremtik meg a biztonságos müködtetés feltételeit. Dél-Korea fôvárosában Szöulban például már több drónos parkot is létrehoztak, a legelső a Gwangnaru Hangang Park volt. Itt a parkon belül kijelöltek egy részt a drónhasználók számára. Nagyon népszerủ a 2016 nyarán megnyitott Hangang Drón Park, ahol már drónröptető ügyességi versenyeket is rendeztek. A versenyekre életkorra tekintet nélkül bárki nevezhet és egy akadálypályát kell időre teljesítenie. A parkban az emberek a saját drónjukat röptetik, egy előre lefoglalt időpontban, de drónkölcsönző is múködik és újabb drónos parkok megnyitását is tervezik. ${ }^{14}$

Nemcsak a drónütközések veszélyesek a városi környezetben, hanem a terroristák vagy más bűnelkövetők is felhasználhatják bűncselekmények elkövetési eszközeként. A városok, illetve az épületek nincsenek megfelelően felkészülve a drónok robbanásszerű, tömeges elterjedésére. Az Európai Légügyi Hatóság (EASA) dolgozik egy összehangolt szabályozásra és egységes definíciókra törekszik például a repüléstilalmi zónák meghatározásában és a korlátozásokat illetően, azonban nagyon sok épület - amelyek között kritikus infrastruktúrához kapcsolódó épületek is vannak - még mindig védtelen.

\section{Milyen dróndetektáló megoldások léteznek?}

Védelem kizárólag csak detektálással lehetséges, erre különböző radarok alkalmasak. Egyik sem 100\%-os, ezért összetett megoldásra van szükség. A jelenleg elérhető egyik legjobb megoldás drónok városi környezetben történő detektálására az amerikai Spotter RF radarrendszere. Kicsi szenzorokat helyeznek el a védendő épületen

14 http://english.seoul.go.kr/hangang-drone-park/ (2018. 09. 07.). 
(tetőn, sarkokon) és ötféle, különböző hatótávolságú radar képes detektálni az épület közelébe kerülő drónokat 130 métertől egészen 1,3 km távolságig terjedően. A radarszoftverek riasztójelzést küldenek az operátornak, aki látja egy távolról irányítható forgókamera segítségével a felbukkanó behatoló drónt, mert a rendszer automatikusan lokalizálja és megjeleníti a monitoron a fő fizikai paramétereivel együtt (ezek a röppálya, a magasság és a sebesség). A riasztójelzés megkönnyíti az adekvát reagálást a biztonsági protokollnak megfelelöen.

\section{Frekvenciazavaráson alapuló elhárítás}

A frekvenciazavaráson alapuló elhárító rendszerek nem újkeletűek, a franciák például Afganisztánban használták a katonai utánpótlást szállító teherautókra telepítve, annak érdekében, hogy az útvonalat biztosítsák, mert a bizonyos gyanús frekvenciákat blokkoló berendezések bombák kiiktatására alkalmasak.

$\mathrm{Az}$ Atos IT-konszern Drone Schield rendszere ${ }^{15}$ megzavarja a légi jármüvek és az irányítórendszerek, navigációs múholdak közötti kommunikációt úgy, hogy egyes frekvenciákat blokkolni tudnak. A legnehezebb feladat az, hogy konkrétan az adott frekvenciára tudják ráállítani az eszközt. Nem szerencsés az összes frekvenciát blokkolni, mert ezáltal nemcsak a saját kommunikációt akadályozzák, hanem rendkívül energiaigényes is. A Drone Schield ahogy neve is mutatja, „pajzsként” múködik, két zónát képez a védendő objektum körül. Ha egy drón berepül az első zónába, akkor megszakad a kapcsolata az irányítóval, ilyenkor a legtöbb kereskedelmi célú, vagy hobbidrón viszszarepül gazdájához, a „home pointra”, kivéve ha egy előre programozott útvonalon közlekedik egy GNSS vevőegység segítségével. Ha a drón továbbrepül a második zónába, akkor már minden jelet blokkolnak, így a drón vagy leszáll vagy lezuhan. A Drone Schield célkitűzése a lezuhanás megakadályozása a személyi- és anyagi károk elkerülése végett. Sajnos egyes drónok esetén frekvenciaugrásokat alkalmaznak a gyártók és ezáltal próbálják kijátszani az elhárító rendszereket. Az optikai és akusztikai szenzorok is javítják az UAV-felderítés hatékonyságát. A rotorhang alapján azonosítást végző akusztikai szenzorok a nagyvárosokban az alapzaj miatt csak kiegészítői lehetnek a védelemnek, mert túl érzékenyek, sok téves riasztást generálhatnak. ${ }^{16}$

\section{Dedrone-technológia}

A német Dedrone cég születését egy 2013. szeptember 15-én történt eseménytől datálja. Ezen a napon Angela Merkel szövetségi kancellár egy választási kampánygyúlésen vett részt Drezdában, ahol több magas rangú CDU-politikussal együtt egy színpadon felállított asztalnál foglalt helyet. Alighogy megnyitották az eseményt, egy drón hirtelen a pulpitus felé repült, 2 méterre megközelítette a kancellárt, majd végül a színpad-

\footnotetext{
Berta (2016)

16 Tarantola (2015)
} 
nak csapódott. Az esetet egy tréfával elütötték és zavartalanul folyt tovább a gyưlés, azonban a cégalapító ötlete megszületett arról, hogy szükséges lenne egy olyan technológia kifejlesztése, amely a civil drónok ellen véd, hisz ha ez a drón fegyverrel felszerelt lett volna, akkor az súlyos következményekkel járt volna. Az incidensért később a „Kalózpárt” vállalta a felelősséget, ugyanis így akarták demonstrálni, hogy megfigyelés alatt tartják Merkel minden politikai lépését. A Deutsche Telekom konszernhez tartozó 2014-es alapítású Dedrone cég terméke a Dedrone-szoftver, amely egy hatékony, valós idejü, többszenzoros védelem a létesítmények és a légtér védelmében. A cég két saját objektumát is ezzel a szoftverrel védi, de a termék széles körű referenciával rendelkezik, például alkalmazzák Katarban a királyi család védelmére vagy az amerikai elnökválasztási kampány során Hillary Clinton és Donald Trump nyilvános vitáinak helyet adó épületet is ezzel biztosították. A védett épületen természetesen IP-kamerákat helyeznek el, valamint radart, jammert (jelzavarót) és különféle szenzorokat. Az ötszörös szenzoros védelem detektálja és azonosítja a behatoló drónt. Előzetesen úgynevezett fekete és fehér listás drónok vannak betáplálva a rendszerbe, tehát ha ellenséges drónt észlelnek, azonnal kezdődhet az elhárítás.

2017. január 17-20. között rendezték meg 47. alkalommal az éves világgazdasági fórumot a svájci Davosban. A Dedrone a konferencia védelmét is ellátta, ezzel mintegy a gyakorlatban demonstrálták a rendszerük hatékonyságát. Előzetesen felvették a kapcsolatot a konferenciának helyet adó Graubünden kanton rendőrségével és megszervezték a védelmet. A Dedrone cég legújabb terméke a DroneTracker 2.5 egy még megbízhatóbb detektálást és azonosítást ígér a behatoló drónok elleni védelemben. A piacvezető Dedrone eredetileg németországi, kasseli székhelyű cég a közelmúltban áttette székhelyét Kaliforniába, San Franciscóba, PR és marketing megfontolásból.

\section{Egyéb drónelhárító módszerek}

Míg Hollandiában a rendőrség „középkori módszerrel”, sasok betanításával történő drónelhárítással próbálkozik, addig Kínában lézeres elhárítást tesztelnek. Japánban bevált a hálóval felszerelt drónelfogó drónegység. A francia székhelyű Airbus Defence and Space radarból és infrakamerából álló rendszert fejlesztett a létesítmények elleni dróntámadások ellen. Oroszország új mikrohullámú ágyúja 360 fokos repüléstilalmi övezetet hoz létre maga körül kb. 10 km-es körzetben, és kisüti bármely repülőgép, drón vagy irányított rakéta elektronikáját.

\section{A drónok rendészeti alkalmazása}

A pilóta nélküli légi jármúvek rendészeti alkalmazására jó példa Angliában a west-midlandsi rendőrség egy kísérleti pilotja, amelynek keretében UAV-k segítségével monitorozták a sportrendezvények résztvevőit, elsősorban a futballmérkőzések közönségét és így preventív módon tudtak fellépni a játékkal összefüggésben előforduló esetleges erőszakos cselekmények vonatkozásában. A pilot értékelése szerint egyértelműen jól 
vizsgáztak a drónok a „huligán” tömegek kezelésében. Különösen hatékony volt a Birmingham City és Aston Villa csapatok nem éppen barátságos szurkoló-táborainak megfékezésében. Az Egyesült Királyságban sem megy azonban minden zökkenőmentesen, míg a West Mindlands Police Department részére hivatalos engedély lett kiállítva a drónok alkalmazására, addig a Brit Polgári Légügyi Hatóság szabályozása tiltja a közvetlen stadionok feletti repülést. A rendőrség azonban így is elégedett, mert a stadionokat körülvevő területek fölötti röptetés is megállítja a huligánokat. A west-midlandsi rendőrség részéről Keith Holliday a következőképp nyilatkozott a Birmingham Mailnek: „A dróntechnológia fantasztikus és kézzelfogható haszna van a modern rendészetben. Ez volt az első alkalom, hogy drónokat alkalmaztunk egy nagy futballmeccs során és fontos szerepet játszottak a drónok a közönség biztonságának garantálásában." ${ }^{17}$

Ausztráliában képviselői kezdeményezésre a queenslandi rendőrség drónokra cserélte helikoptereit két okból kifolyólag: a drónok üzemeltetése kisebb költséggel jár, másrészt alkalmazásukkal jelentősen csökken a reakcióidő. New South Wales rendőrsége már korábban hasonlóan járt el és mivel a drónok beváltották a hozzájuk füzött reményeket, újabb 100 tagú drónflotta alkalmazását tervezik a bűnüldöző szerveknél.

A floridai rendőrök 2016 novemberétől kezdődően már kiképzést kapnak a drónok biztonságos kezelésére. A repülésbiztonsági oktatásban 30 éves tapasztalattal rendelkező, 2014-től USI (Unmanned Safety Institute) néven működő intézet pilóta nélküli légi járművek biztonságos üzemeltetését oktatja és kutatja, a floridai rendőrség velük kötött megállapodása biztosítja a rendőrök színvonalas kiképzését. A rendőrök workshopokon is részt vesznek, ahol az erőszakos drónbehatolásokra való megfelelő reagálásra készítik fel őket.

\section{A Battelle cég DroneDefendere}

A Battelle nevű amerikai cég 2015 őszén mutatta be a „DroneDefender” nevü drónelhárító puskáját. Alex Morrow, a Battelle műszaki igazgatója szerint könnyen és megbízható módon lehet a drónpuskával semlegesíteni a fenyegetéseket. A fegyver súlya mindössze 10 font, azaz 4,5 kg és a hatótávolsága 400 méter. A DroneDefender rádióhullámokat indít a célpontra: egyrészt blokkolja drónhoz érkező rádiójeleket, másrészt pedig az eredeti jeleket a saját maga által küldött jelekkel „felülírva” leszállásra tudja kényszeríteni a drónokat. Az eszköz a leggyakrabban használt GPS- és ISM-frekvenciákon múködik, és a gyártó szerint a drónok széles palettája ellen hatékony és különösen hasznos lehet robbanóanyagot szállító ellenséges drón esetén. Az USA-ban a Fehér Ház és kertjének védelme mellett a nagykövetségek, iskolák vagy történelmi helyszínek védelmére is használják.

A drón és az operátor közötti kommunikáció megszűnésekor vagy lezuhan a drón, vagy visszatér a felszállási helyére. Mindenképpen a második eset a szerencsés, mert így az operátort számon tudjuk kérni, a lezuhanó drón pedig balesetet, anyagi kárt

17 Lockley (2018) 
okozhat, illetve felrobbanhat stb. (Általában az optikai szenzorral rendelkező drónok repülnek vissza a kiindulási pontra. $)^{18}$

\section{A Hikvision Anti-Drone Gunja}

Már hazánkban is elérhető a kínai Hikvision által gyártott antidrón puska. A cég képviselői a Riel Elektronikai Kft.-vel együtt 2017. március 24-én Budapesten tartottak egy nagyon látványos, meggyőző bemutatót a megrendelői oldalnak, amely eseményen jómagam is jelen voltam. Az antidrón puska pillanatok alatt müködésképtelenné tette a bevásárlóközpontokban is megvásárolható 50 ezer forintos hobbidrónt, és az azonnal lezuhant a pázsitra. Ezt a múveletet tucatnyi alkalommal megismételték, mindig ugyanazon eredménnyel. A hobbidrónban sérülés nem keletkezett. A puska nagyon könnyú, egyszerű a kezelése: a szálkereszt célra irányítása és az elsütőbillentyư lenyomása. Az akkumulátor 10-15 „lövésre” elég, ezután a tartalékakkumulátort lehet alkalmazni.

\section{Konklúzió}

Új szabályozásra van szükség a drónok használatának korlátozása végett Európában, de ez a szabályozás nem lehet aránytalanul szigorú sem, hogy ne riassza el a befektetőket. Fontos szempont, hogy a pilóta nélküli légi járművek idejében és adekvát módon tudják felismerni a légtérben repülő légi jármúveket, és ne veszélyeztessék a fedélzetükön emberekkel repülő gépeket. A sűrűn lakott területek felett, illetve a repülőterek-, erőművek-, nukleáris- és vegyi üzemek védelmére kiemelt figyelmet kell fordítani. Fontos szempont a drónokkal kapcsolatos adatvédelmi kérdések megoldása is, adatvédelmi területen már van uniós és nemzeti szintű szabályozás egyaránt.

Nem elég észszerű szabályozást kialakítani, szükség van jogkövető és felelősen gondolkodó állampolgárokra is. Mindenképpen könnyíteni kell az engedélyezést és a modern technika vívmányait alkalmazva felhasználóbaráttá tenni az engedélyhez jutás folyamatát, ugyanakkor megfelelő garanciális feltételek megléte szükséges a biztonságos drónhasználat gyakorlatának kialakításához. Nem elhanyagolható a felhasználóknak nyújtott közérthető tájékoztatás sem.

A német gyakorlatból javaslom átvenni a videoszemüveg használatát annak érdekében, hogy a 250 gramm alatti tömegü drónok is megfelelöen kontrollálva legyenek a drónhasználat közben, hiszen relative alacsony áruk miatt ezek nagy számban vannak jelen a légtérben. A brit gyakorlatból javaslom átvenni azt, hogy egy esetlegesen bekövetkező baleset során a felelősség a tulajdonost terhelje minden esetben, így a kivizsgálás nem a jellemzöen túlterhelt rendőri szervek felelössége lesz. A japán gyakorlatból javaslom átvenni a közüzemektöl (például elektromos felszini vezetékek) való minimális távolság betartását. A dél-koreai gyakorlatból javaslom átvenni a drónröptetés területi behatárolásának azt a módszerét, amely

18 Tarantola (2015) 
során egy rendeltetésszerüen müködtetett közparkban jelölnek ki drónparkot. Továbbá a DélKoreában alkalmazott időbeli behatárolás átvételét is javaslom megfontolni, amely szerint kizárólag napkelte és napnyugta között lehet használni a drónokat, a drónbalesetek megelőzése érdekében. Szintén a bevezetését javaslom egy nemzeti drónregiszternek, amit egy állami szervezet tart nyilván, illetve müködtet.

Tudjuk, hogy száz százalékos biztonság nem létezik, de reméljük, hogy a drónelhárító technológiák és a jogszabályi garanciák képesek lesznek lépést tartani a drónok gyors, tömeges elterjedésével.

\section{IRODALOMJEGYZÉK}

Atherton, Kelsey D. (2015): In Japan, Drones Guide Robot Trucks At Construction Sites, More machines, fewer humans. Forrás: www.popsci.com/in-japan-drones-guide-robot-trucks-at-construction-sites (2018. 09. 07.)

Berta Sándor (2016): Frekvencia-zavarás a drónok ellen. 2016. 02. 13. Forrás: https://sg.hu/cikkek/ittech/117590/frekvencia-zavaras-a-dronok-ellen (2018. 09. 11.)

Lockley, Mike (2018): How police are using DRONES to tackle football hooligans. 2018. 01. 11. Forrás: www.birminghammail.co.uk/news/midlands-news/how-police-using-drones-tackle-14012400 (2018. 09. 11.)

Magyar Tamara (2017): Új törvény érvényes a drónokra Németországban. Forrás: http://nemetorszagimagyarok.de/hirek/torveny-a-dronokrol 2017. 04. 14. (2018. 09. 11.)

Mogg, Trevor (2015a): Japanese police plan to battle drones with even bigger drones, equipped with nets. 2015. 12. 10. Forrás: www.digitaltrends.com/cool-tech/japan-cracks-down-on-hobbyist-droneswith-new-laws/ (2018. 09. 11.)

Mogg, Trevor (2015b): Watch Japanese cops use a net-equipped drone to catch a 'rogue' quadcopter. 2015. 12. 14. Forrás: www.digitaltrends.com/cool-tech/watch-japans-bizarre-net-wielding-police-drone-in-action/ (2018. 09. 07.)

Novák Csaba (2015): Amikor a drón befejezi röptét... Minden, amit a jogszerű drónhasználatról tudni kell. In Radványi Róbert szerk.: Biztonságpiaci évkönyv. Budapest.

Shin \& Kim (2018): New Korean drone laws. 2017. 02. 08. Forrás: https://www.shinkim.com/attachment/318 (2018. 09. 06.)

Sipos Attila (2017): A polgári légi jármú jogi státusza. Repüléstudományi Közlemények, 29. évf. 3. sz. 273-300.

Tarantola, Andrew (2015): Anti-drone rifle shoots down UAVs with radio waves. 2015. 10. 14. Forrás: www. engadget.com/2015/10/14/anti-drone-rifle-shoots-down-uavs-with-radio-waves/ (2018. 09. 10.)

\section{Internetes források}

https://droninfo.blog.hu/2018/06/12/jovahagytak_az_eu_dronszabalyozast 2018. 06.12. (2018. 09. 07.) https://droninfo.blog.hu/2018/08/03/uj_drontorveny_lepett_eletbe_angliaban 2018. 08. 03. (2018. 09. 10.)

http://english.seoul.go.kr/hangang-drone-park/ (2018. 09. 10.)

www.uavsystemsinternational.com/drone-laws-by-country/japan-drone-laws/?v=35b5282113b8

(2018. 09. 07.) 


\section{ABSTRACT}

\section{Increased and Even More Tighter Regulations on Using Drones}

ROTTLER Violetta

Private security industry is in a continuous change. In several areas a fundamental paradigm shift can be seen. The integrated security solution (manned guarding with electronic defence) is the leading trend and drones play an increasing role in that. The goal of this paper is to give a short overview about the current regulation in Hungary, in the European Union and to show some regulation examples from abroad. In my opinion, using drones in law enforcement should be increasingly important. To create a proper national regulation, it can be useful to get familiar with the different foreign resolutions.

Keywords: drone, drone regulation 